\title{
EKPLOITASI TUBUH AKTIVIS PEREMPUAN PENGURUS CABANG PERGERAKAN MAHASISWA ISLAM INDONESIA KABUPATEN MALANG
}

\author{
Ahmad Zainuri \\ Yayasan Kebangsaan Kemanusiaan Indonesiajl. Ahmad Yani No \\ 60 Gambiran 65163, Gambiran, Mojosari, Kec. Kepanjen, Malang. \\ Email: ahmadzainuri706@gmail.com
}

\begin{abstract}
In implementing the works program of the Branch Management of Indonesian Islamic Students Movement of Malang Regency, for the sake of a good and interesting event, the owners of power use female activists to become workers. Women activists must carry out tasks that are not in accordance with their job descriptions, get coercion from fellow activists to carry out tasks that they themselves have not yet experienced and only try first, and the most striking is when female activists are not bappy if there is a women's development program. The practice of exploitation of these women activists, seen in this article, uses Michel Foucault's body discipline theory. The body's discipline works as a normalization of behavior designed by utilizing the productive and reproductive abilities of the buman body. The practice of power through disciplining the body, creates a situation where the individual body can internalize submission and make it look like a normal state. This practice is what Foucault calls the normalization of power over the individual body. Individuals will never feel that they are being used and subjugated because they already consider it to be within reasonable limits. It can also be said that this is a veiled exploitation.
\end{abstract}

Keywords: Body exploitation, women activists, and Indonesian Islamic Students Movement

\begin{abstract}
Abstrak: Dalam pelaksanaan program kerja Pengurus Cabang Pergerakan Mahasiswa Islam Indonesia Kabupaten Malang, demi terlaksanya acara yang bagus dan menarik, para pemilik kekuasaan memanfaatkan aktivis perempuan untuk menjadi pekerja. Aktivis perempuan harus melaksanakan tugas yang tidak sesuai dengan deskripsi kerjanya, mendapat paksaan dari teman sesama aktivis untuk melaksanakan tugas yang dia sendiri belum berpengalaman dan baru pertama mencobanya, dan yang paling mencolok adalah ketika sesama aktivis perempuan tidak senang jika ada program pengembangan keperempuanan. Praktik eksploitasi terhadap aktivis perempuan tersebut, dilihat dalam artikel ini, menggunakan teori disiplin tubuh Michel Foucault. Disiplin tubuh bekerja sebagai normalisasi kelakuan yang didesain dengan memanfaatkan kemampuan produktif dan reproduktif dari tubuh manusia. Praktik kekuasaaan melalui pendisiplinan tubuh, menciptakan situasi dimana tubuh individu dapat
\end{abstract}

AL-HUKAMA

The Indonesian Journal of Islamic Family Law Volume 09, Nomor 01, Juni 2019; ISSN:2089-7480 
menginternalisasikan penundukan dan menjadikannya seolah sebagai suatu keadaan yang normal. Praktik seperti inilah yang disebut Foucault sebagai normalisasi kekuasaan terhadap tubuh individu. Individu tidak akan pernah merasa sedang dimanfaatkan dan ditundukkan karena mereka sudah menganggap hal itu sesuai batas kewajaran. Bisa dikatakan juga bahwa ini adalah eksploitasi yang terselubung.

Kata kunci: eksploitasi tubuh, aktivis perempuan, dan PMII.

\section{Pendahuluan}

Mahasiswa yang sedang menuntut ilmu di perguruan tinggi negeri maupun swasta, akan dihadapkan pada kenyataan sosial kemahasiswaan yang membuatnya harus beradaptasi karena dunia yang sangat berbeda jauh dibandingkan dengan masa-masa SMA/sederajat. Jika sudah menyandang gelar mahasiswa maka akan dihadapkan dengan permasalahan yang lebih besar dan sekaligus tanggung jawab yang tak kalah besar pula. Mahasiswa akan menjadi agent of change dan agent of social control kelak di kemudian hari setelah mereka lulus dari perguruan tinggi. Mahasiswa dituntut harus dapat bersosialisai dengan baik dan mempunyai kecakapan yang masyarakat secara umum butuhkan.

Ada macam-macam jenis mahasiswa dalam satu lingkup perguruan tinggi, tetapi penulis akan memfokuskan kepada mahasiswa yang aktif bersosialisasi dan berorganisasi baik di organisasi mahasiswa intra kampus (ORMIK) maupun ada organisasi mahasiswa ektra kampus (ORMEK). Penulis memfokuskan penelitian kepada para mahasiswa aktivis yang sedang berproses di dalam sebuah organisasi mahasiswa ektra kampus (ORMEK).

Ada banyak jenis ormek yang tersebar di seluruh penjuru negeri ini, di Kabupaten Malang ada GMNI (Gerakan Mahasiswa Nasional Indonesia), HMI (Himpunan Mahasiswa Islam), dan PMII (Pergerakan Mahasiswa Islam Indonesia). Setiap organisasi tentu memiliki ciri khas dan corak tersediri dalam menerapkan program kerja meraka, dimulai dari perekrutan anggota baru sampai kepada sebaran anggota/ kader meraka di setiap lini yang mereka ingin kuasai, baik ingin menguasai Ormik atau Ormek internalnya, pasti memiliki cara yang berbeda. Dikarenakan mereka memiliki senior dalam setiap organisasinya yang siap meneteskan ilmu yang pernah 
didapat untuk para juniornya. Karena pengaruh kultural ini menjadikan setiap organisasi memilik cara dan ciri yang berbeda dalam menjalankan program kerja yang telah mereka canangkan sejak awal kepengurusan yang mereka bentuk.

Di sini penulis ingin membahas cara bagaimana mereka menjalankan dan menyelesaikan program kerja. Setiap anggota dan kader akan mendapat peran untuk dapat membuat program kerja menjadi sukses. Tentunya juga pengurus dari setiap lini yang ada di garis hierarki keorganisasian membantu untuk merealisasikan program kerja yang sudah dirancang sedemikian rupa untuk meningkatkan kualitas sekaligus kuantitas dari setaip organisasi yang meraka ikuti dan tekuni. Baik laki-laki maupun perempuan mendapatkan jatah program yang proporsional untuk diselesaikan dan dikerjakan. Dari titik ini penulis menggarisbawahi, bahwa tugas yang didapat adalah tugas yang proporsional.

Sebelumnya, penulis ingin membahas lebih dalam satu Ormek saja, yakni PMII (Pergerakan Mahasiswa Islam Indonesia). Agar dapat lebih fokus dan rinci untuk membahas permasalahan di dalam tubuh PMII. Dalam proses pelaksanaan program kerja organisasi PMII, mulai dari program kerja kaderisasi formal, dan nonformal. Kaderisasi formal seperti: Mapaba (Masa Penerimaan Anggota Baru), PKD (Pelatihan Kader Dasar), PKL (Pelatihan Kader Lanjut).1 Sedangkan kaderisasi non-formal adalah kelanjutan dari kaderisasi formal, yaitu mengembangkan potensi kader berbasis soft skill, seperti: pelatihan-pelatihan dan/atau seminar-seminar.2

Masalahnya muncul ketika dalam pelaksanaan program kerja ini, eksploitasi tubuh aktivis perempuan dimulai: mulai menjadi ketua panitia, pembawa acara, mengantarkan sajian/hidangan ke dalam forum, menjadi dirijen, menjadi moderator, menjadi protokoler, penyaji hiburan, penerima tamu, model dalam pamflet, atau tugas rekrutmen anggota baru dipilih yang bisa dikatakan berparas cantik dan menarik perhatian. Ini adalah beberapa contoh dari pelaksanaan program kerja yang bersifat formal, informal dan non-formal. Sebelum acara dimulai pun eksploitasi ini sudah

1"Hasil Muspimnas - Pergerakan Mahasiswa Islam Indonesia," accessed May 8, 2019, https://pmii.or.id/hasil-muspimnas/.

2Ibid. 
dijalankan dengan menjadikan perempuan sebagai humas yang difungsikan untuk berkomunikasi dengan anggota, senior dan/atau instansi yang berkaitan dengan acara yang akan dilaksanakan, lagilagi memilih anggota atau kader yang dapat dikatakan berparas cantik dan menarik perhatian, agar anggota dan/atau kader yang mengikuti sebuah agenda yang dijalankan semakin banyak dan meriah.

Hal-hal tersebut seakan sudah menjadi budaya mainstream dalam sebuah pelaksanaan program kerja. Para aktivis perempuan yang dieksploitasi tersebut tidak sadar jika sedang dieksploitasi tubuhnya oleh sesama aktivis. Mereka menganggapnya sebagai suatu kewajaran dan menjadi tugasnya sebagai aktivis perempuan. Ini adalah salah satu bentuk eksploitasi tubuh terhadap aktivis perempuan yang perlu untuk diadakan perubahan atau tindakan penyadaran bagi pelaku maupun korban eksploitasi. Jika dibiarkan berlarut-larut, yang ditakutkan adalah para aktivis ini dengan tidak sadar akan menerapkan dalam kehidupan bermasyarakat kelak setelah purna dari perguruan tinggi dan budaya ini akan diwariskan kepada juniornya untuk dilanggengkan kepada generasi selanjutnya sebagai budaya biasa dan pantas untuk dilakukan terus menerus.

Perempuan secara kodratnya memang diciptakan menarik, indah dan mempesona. Kapitalis memanfaatkan kodrat perempuan tersebut untuk mengembangkan bisnis yang mereka miliki. Zaman sekarang sulit sekali memisahkan antara kapitalis dan perempuan, karena hampir semua bidang bisnis dari kapitalis seperti: film, televisi, iklan, dan termasuk perdagangan pasti akan memasukkan unsur perempuan untuk dapat mengembangkan bisnis dan jika bisnisnya berkembang maka keuntungan yang dapat diraup akan banyak dan meningkat. Disinilah kaum kapitalis memegang kendali.3

Begitupun juga dalam dunia aktivis, tubuh aktivis perempuan menjadi suatu komoditas yang dapat digunakan untuk memperlancar urusan berhadapan dengan senior yang lumayan sulit jika berdialog dengan sesama jenis. Kemudian aktivis perempuan dimanfaatkan untuk menghadapi senior tersebut. Eksploitasi tubuh

3 M.Syamsudin.“Eksploitasi Wanita dalam Perspektif Kapitalis”, E-jurnal Egalita, 1 (2): 20-40, (2006). 6. 
aktivis perempuan dimulai, bukan hanya dari sekedar menyelesaikan tugas humas, tetapi juga mulai menjadi ketua panitia, pembawa acara, mengantarkan sajian/hidangan ke dalam forum, menjadi dirijen, menjadi moderator, menjadi protokoler, penyaji hiburan, penerima tamu. Mereka dipilih yang cantik dan menarik perhatian. Ini adalah beberapa contoh dari pelaksanaan program kerja yang bersifat formal dan dibungkus dalam bentuk sebuah acara.

Dengan sekelumit alasan yang penulis jabarkan di atas, maka penulis lebih tertarik untuk hanya meneliti eksploitasi terhadap aktivis perempuan. Meskipun aktivis laki-lakinya juga pernah dan ada yang tereksploitasi oleh pelaksanaan program kerja, tetapi tidak banyak. Penulis cenderung untuk meneliti aktivis perempuan dikarenakan para aktivis perempuan ini juga sedang berjuang melawan stigma terhadap kodrat mereka menjadi perempuan, di mana di tempat penelitian ini dilaksanakan, budaya patriarki sangat massif, mengakar, dan membudaya. Mereka terkadang belum bisa membedakan mana tugas perempuan mana tugas laki-laki.

\section{Eksploitasi Tubuh}

Menurut Kamus Besar Bahasa Indonesia (KBBI), eksploitasi merupakan suatu tindakan pemanfaatan untuk kepentingan sendiri, pengisapan dan pemerasan (tenaga orang) atas diri orang lain dan merupakan tindakan yang tidak terpuji. Eksploitasi yang dialami perempuan dalam hal ini adalah salah satu bentuk ketidakadilan gender.4

Eksploitasi menurut Glosarium seks dan gender berarti memanfaatkan tubuh seseorang (perempuan) untuk kepentingan sesuatu, misalnya dalam dunia bisnis. Penindasan perempuan yang malah dilanggengkan oleh berbagai cara dan alasan karena menguntungkan.5 Menonjolkan tubuh perempuan, misalnya menampilkan perempuan dengan pakaian ketat: melakukan gerakan

4"Arti Kata Eksploitasi - Kamus Besar Bahasa Indonesia (KBBI) Online," accessed May 25, 2019, https://kbbi.web.id/eksploitasi.

5"Eksploitasi Tubuh Perempuan Di Media Televisi (Analisis Semiotika Makna Pesan Iklan Cat Avian Syntetic Versi Awas Cat Basah) | Lago | KINESIK," $\begin{array}{llll}\text { accessed } & \text { May 20, } & \end{array}$ http://jurnal.untad.ac.id/jurnal/index.php/Kinesik/article/view/8761. 
erotis dan sensual berupa goyangan pinggul; serta memperlihatkan ekspresi sensual perempuan.

Eksploitasi memiliki arti suatu tindakan untuk memanfaatkan sesuatu secara berlebihan atau sewenang-wenang demi kepentingan pengguna dan dapat menimbulkan kerugian pada lingkungan sekitar maupun terhadap orang lain. Sedangkan yang dimaksud dengan eksploitasi perempuan adalah, pemanfaatan segala hal yang melekat pada perempuan, baik citra maupun tanda yang melekat kepada dirinya6 dan meninggalkan unsur pemenuhan hak-hak dari perempuan.7

Dalam jurnal karya Nur Afta Lestari tahun 2012 tertulis, bahwa terdapat lima bentuk eksploitasi yaitu: 1) Eksploitasi seksual, dimana mereka yang terlibat dalam kegiatan prostitusi, pelayanan/pekerja seks, atau menjadi obyek kegiatan pornografi yang dikarenakan oleh ancaman pemaksaan, penculikan, diperlakukan dengan salah, menjadi orang yang dijual (debt bondage) atau karena menjadi korban penipuan; 2) Kerja paksa (forced labour) : segala bentuk pekerjaan atau pelayanan yang di dapat (pelaku) dengan menggunakan tenaga orang yang berada di dalam ancaman hukuman dan orang tersebut bekerja melayani tanpa keinginannya sendiri secara sukarela; 3) perbudakan (slavery) : keadaan (status) dan kondisi seseorang terhadap siapa hak pemilikan (dari orang lain) diberlakukan terhadapnya; 4) pengahambatan : status atau kondisi orang-orang yang berdiam di atas tanah milik orang lain yang menurut hukum kebiasaan atau perjanjian terikat untuk hidup dan bekerja di atas tanah tersebut dan wajib mengabdi kepada orang tersebut, baik dengan imbalan maupun tidak dan ia tidak bebas mengubah statusnya itu; dan 5)Pengambilan organ-organ tubuh: trafficking dari pengambilan organ-organ tubuh hanya muncul jika seseorang dipindahkan untuk tujuan pemindahan organ dan

6Ignatius Prasetyo Wicaksono, "Representasi Eksplotasi Perempuan dalam Iklan”, Jurnal Ilmu Komunikasi, volume 9 nomor 2 (desember, 2012), 149-154.

7"Eksploitasi Pada Perempuan Sales Promotion Girls | Afta Lestari | Komunitas: International Journal Of Indonesian Society And Culture," accessed May 25, 2019, https://journal.unnes.ac.id/nju/index.php/komunitas/article/view/2402. 
protokol ini tidak mengatur jika hanya berupa pemindahan organ (organ yang dipindahkan sudah tidak berada dalam tubuh lagi).8

Eksploitasi terhadap kaum perempun secara umum di definisikan sebagai suatu tindakan menggali atau memanfaatkan sumber daya yang dimiliki oleh manusia khususnya terhadap perempuan secara berlebihan dan memiliki dampak yang dapat merugikan pihak perempuan.

Yasraf Amir Piliang mengatakan "Tubuh, khususnya perempuan, di dalam wacana kapitalisme tidak saja di eksplorasi nilai gunanya (use-value)- pekerja, prostitusi, pelayan; akan tetapi juga nilai tukarnya (exchange-value)- gadis model, gadis peraga, hostess; dan kini juga nilai tandanya (sign-value)- erotic magazine, erotic video, erotic photography, erotic film, erotic ved." yang di tulis dalam skripsi Ayu Handani yang berjudul Eksploitasi Tubuh Perempuan pada Sales Promotion Girls.9

\section{Disiplin Tubuh Menurut Michel Foucault}

Salah satu kontribusi besar Foucault dalam bidang filsafat dan politik adalah konsepnya tentang kekuasaan. Berbeda dengan para pemikir lain yang telah menguraikan konsep-konsep kekuasaan, Foucault menampilkan suatu perspektif kekuasaan secara baru. Menurut Foucault, kekuasaan bukanlah sesuatu yang hanya dikuasai oleh negara, sesuatu yang dapat diukur. Kekuasaan bagi dia ada di mana-mana, karena kekuasaan merupakan satu dimensi dari relasi. Artinya, di mana ada relasi, di sana ada kekuasaan. Di sinilah letak kekhasan Foucault. Dia tidak menguraikan apa itu kuasa, tetapi bagaimana kuasa itu berfungsi pada bidang tertentu.

Sebenarnya yang hendak dibuat Foucault adalah menunjukkan bahwa kita adalah bagian dari mekanisme kekuasaan itu. Dari kesadaran ini akan lahir kesanggupan untuk menggunakan kekuasaan secara baik, artinya demi kepentingan orang lain. Keterarahan pada orang lain hanya lahir dari kesadaran akan tempat diri sendiri dalam konstelasi kekuasaan. Yang menjadi masalah

8 Nur Afta Lestari, "Eksploitasi Pada Permpuan Sales Promotion Girls", Jurnal Komunitas, Komunitas 4 (2) (2012), 141.

9 Ayu Handani, Ekesploitasi Tubuh Perempuan Pada Sales Promotion Girl (Studi Kasus Komunikasi Non Verbal Sales Promotion Girl Produk Rokok) 
dalam kehidupan adalah bahwa banyak orang tak menyadari perannya dalam peta kekuasaan. Apabila orang sadar akan hal ini, maka orang pun akan menerima dan menghargai pluralitas peran yang ada dalam relasi kekuasaan. Dari ketidaksadaran ini akan lahir berbagai tindakan dan sistem yang menindas dan menyeragamkan.

Kekuasaan adalah sesuatu yang dilegitimasikan secara metafisis kepada negara yang memungkinkan negara dapat mewajibkan semua orang untuk mematuhinya. Namun menurut Foucault, kekuasaan bukanlah sesuatu yang hanya dikuasai oleh negara, sesuatu yang dapat diukur. Kekuasaan ada di mana-mana, karena kekuasaan adalah satu dimensi dari relasi. Di mana ada relasi, di sana ada kekuasaan.10

Kuasa itu ada di mana-mana dan muncul dari relasi-relasi antara pelbagai kekuatan, terjadi secara mutlak dan tidak tergantung dari kesadaran manusia. Kekuasaan hanyalah sebuah strategi. Strategi ini berlangsung di mana-mana dan di sana terdapat sistem, aturan, susunan dan regulasi. Kekuasaan ini tidak datang dari luar, melainkan kekuasaan menentukan susunan, aturan dan hubunganhubungan dari dalam dan memungkinkan semuanya terjadi.11

Kuasa yang biasa dipahami dengan kekuatan yang hanya bisa membatasi, menekan atau melarang. Kuasa juga biasa dipahami sebagai kekuatan negatif. Kedua anggapan tersebut dapat dipahami dalam kerangka yang menempatkan kuasa menjadi 'milik', contohnya adalah kuasa absolut dari seorang raja pada zaman dahulu atau juga seperti lembaga hukum yang mempunyai kekuatan untuk mengklaim atau menentukan status seseorang sebagai seorang yang bersalah dan layak dihukum atau tidak bersalah dan ahirnya bebas.

Foucault menelusuri perubahan 'teknologi' politis terhadap tubuh dan menemukan bahwa kuasa itu bukan 'milik' melainkan sebagai mekanisme, kuasa yang bermodelkan mekanisme ini lebih efektif dalam 'menyentuh' targetnya. Hal ini terlihat dalam pelaksanaan kuasa menghukum dari model yang menyentuh tubuh secara langsung dan kejam sekaligus dipertunjukkan di depan khalayak ramai, misalnya di tengah alun-alun kota, menuju

10 K. Bertens, Filsafat Barat Kontemporer Prancis (Jakarta: Gramedia, 2001), 307-310. 11 Ibid, 319. 
pelaksanaan hukuman yang sama sekali tidak menyentuh tubuh tetapi mengenenai realitas non-korporal individu. Lebih mengarah kepada koreksi dan normalisasi terhadap individu yang terkena hukuman untuk menjadkannya individu yang patuh dan berguna, dengan demikian membuat kuasa menjadi kekuatan yang sangat produktif.

Hampir dalam seluruh uraiannya tentang kekuasaan, Foucault menggunakan gagasan dari orang lain sebagai bahan, tetapi selalu diolah dan dimasukkan secara inovatif ke dalam bangunan konsepnya sendiri. Sebab itu kita dapat menemukan konsep Nietzsche di sana. Dia menjadikan uraian Nietzsche tentang kekuasaan sebagai basis refleksi kebudayaan dan filosofisnya. Filsafat politik tradisional selalu berorientasi pada soal legitimasi. Kekuasaan adalah sesuatu yang dilegitimasikan secara metafisis kepada negara yang memungkinkan negara dapat mewajibkan semua orang untuk mematuhinya. Namun menurut Foucault, kekuasaan bukanlah sesuatu yang hanya dikuasai oleh negara, sesuatu yang dapat diukur. Kekuasaan ada di mana-mana, karena kekuasaan adalah satu dimensi dari relasi. Di mana ada relasi, di sana ada kekuasaan.12

Dalam buku terjemahan karya Petrus Sunu Hardiyanto13 menerangkan tentang Diciplin and Punishment. Dalam buku ini ditulis bahwa Foucault hendak mengetengahkan relasi kekuasaan yang bergerak melalui wacana berakibat pada rasa sakit pada tubuh manusia. Pengamatannya pada praktek disiplin penjara membuktikan hal itu. Foucault memulai pergerakan wacana dengan menyampaikan kisah sejarah tentang hukuman yang terus bergeser sesuai zamannya. Sistem hukuman yang berpusat pada rasa sakit yang dipertontonkan secara terbuka menjadi tidak terkontrol dan dapat memicu kerusuhan atau huru hara politik. Seluruh sistem hukuman yang berpusat pada rasa sakit dirancang dan dijalankan lantas direduksi menjadi satu hukuman untuk semua jenis kejahatan, hukuman penjara. Masyarakat sudah terbiasa dengan wacana ini dan

12 Michel Foucault, Seks dan Kekuasaan, terj. S. H. Rahayu (Jakarta: Gramedia, 2000), 144

13 Petrus Sunu Hardiyanto, Disiplin Tubub Bengkel Individu Modern (Yogyakarta: LKiS, 1997), 22. 
sulit untuk kembali pada wacana hukuman mati yang dipertontonkan secara terbuka sebelumnya. Dalam penjara terdapat satu bangunan yang dirancang untuk mengawasi seluruh tahanan. Desain bangunan ini dinamakanPanopticon. Panopticon berfungsi sebagai tempat pengawasan tahanan yang ditempati oleh sipir penjaga tahanan untuk memastikan para tahanan yang ada didalamnya melaksanakan disiplin yang sudah menjadi peraturan tahanan.

Teknologi politis ini,14 memastikan tubuh individu menjadi patuh dan taat terhadap peraturan atau disiplin yang sudah menjadi kebijakan seseorang yang memiliki kuasa. Teknologi politis ini sampai detik ini diterapkan kedalam penjara-penjara dan rumah sakit-rumah sakit, yang tentunya digunakan untuk mempermudah pelayanan. Sebagai contoh teknologi politis ini adalah semua individu yang masuk kedalam institusi tersebut akan dicatat seluruh data dirinya dengan tujuan untuk memudahkan mengenali dan menganalisisnya untuk diperbaiki kedisiplinannya.

Foucault membatasi wilayah dan metodologi penelitiannya untuk menggambarkan timbal-balik antara kuasa dan individu, Diciplin and Punish:Foucault tidak memusatkan studi mengenai pelaksanaan kuasa menghukum pada efeknya yang menekan semata-mata, atau padasegi negatif penghukuman saja, melainkan menempatkan dalam seluruh rangkaian 'akibat positif yang 'mungkin' bahkan dalam bentuk yang amat marginal, Memandang hukuman sebagai suatu fungsi sosial yang kompleks,Menganalisis metode menghukum bukan sebagai akibat dari hukum atau ketentuan lembaga pengadilan, tetapi sebagai strategi politik dan sebagia teknik yang tersebar dalam masyarakat dan tampil daam cara-cara pelaksanaan 'kuasa' yang lebih luas dan umum,Menjadikan 'teknologi kuasa' sebagai prinsip dasar humanisasi sistem penghukuman dan pengetahuan mengenai manusia; dan menelaah diikutsertakannya 'jiwa' dari individu modern kedalam wilayah

14Ibid, 34 . 
peradialan hukuman dan ke dalam pembentukan tubuh pengetahuan ilmiah. 15

Menurut Umar Kamahi,16disciplinary power atau kekuatan pendisiplinan Ini bisa menjadi produktif, dikarenakan mengontrol tubuh melalui sebuah mekanisme pengawasan yang diinternalisasikan menjadi sebuah proses normalisasi berjalannya kekuasaan terhadap tubuh. Menurut Foucault, subjek modern merupakan kendaraan bagi kekuasaan dan objek bagi pengetahuan. Disciplinarypower adalah bentuk kekuasaan itu sendiri dan teknologi kekuasaan beroperasi melalui pendisiplinan tubuh. Jadi tubuh merupakan sebuah alat untuk melanggengkan sebuah kekuasaan.Disciplinary power itu berbeda sekali dengan soveriegnitypower. Jika disciplinarypower hanya menggunakan tubuh melalui mekanisme pengawasan dan tanpa pemaksaan maka sovereignitypower sebaliknya, dia menggunakan kekuasaan kedaulatan untuk menundukkan perilaku melalui kepatuhan terhadap hukum.

Dari sinilah Foucault mulai memberi pembatasan atau defenisi tentangkekuasaan sebagai inti dari pokok fikirannya. Menurut Foucault, kekuasaanadalah aneka ragam hubungan kekuatan yang ada di dalam ruang lingkuptempat hubungan itu berjalan yang mewujudkan organisasinya sendiri. Dalam pengertian tradisional, kekuasaan itu bersifat monolitis, hirarkisdan dapat dilihat dengan jelas. Kekuasaan dapat terwujud dalam Undang-undang yang dituliskan.

Hal tersebut menggambarkan dengan baik praktik kekuasaan dalam sistem monarki tradisional.Namun saat ini, praktek kekuasaan sudah berkembang dalam metode-metodebaru. Metode baru kekuasaan tidak dijamin oleh hak, tetapi olehteknik. Kekuasaan tidak dijamin oleh Undang-undang, tetapi melaluiproses normalisasi. Kekuasaan tidak ditegakkan oleh hukuman tetapi olehsistem kontrol. Metode yang digunakan untuk menunjukkan kekuasaanpada semua tingkat, melampaui negara dan aparatnya. Dalam hal iniFoucault memberi contoh stigma antara normal dan

15Ibid, 32.

16Abdil Mughis Mudhoffir, "Teori Kekuasaan Michel Foucault: Tantangan bagi Sosiologi Politik," Masyarakat: Jurnal Sosiologi 18, no. 1 (January 3, 2013), accessed April 1, 2019, http://journal.ui.ac.id/index.php/mjs/article/view/3734. 
sakit, benar dan salahatau baik dan dosa merupakan bentuk lain praktek kekuasaan. Bentukbaru kekuasaan ini jauh lebih halus daripada kekuasaan dalam pengertiantradisional. Oleh karena itu, menjadi jauh lebih mudah mengabaikannyatetapi justru lebih sukar melawannya.17

Foucault hanya menegaskan bahwasannya tidak ada kekuasaan yangdilaksanakan tanpa serangkaian tujuan dan sasaran yang pasti. Foucault tidak memberi jalan keluar bagaimana melepaskan diri darikekuasaan tersebut. Alasanya, karena kekuasaan berjalan melalui prosesnormalisasi, maka tidak ada lagi orang yang mengurusi kekuasaan, olehkarena itu tidak ada orang yang dapat dipersalahkan. Dalam kondisi'normal' seperti itu, apakah ada cara untuk melawan? Dalam pandanganskeptis demikian, Foucault memberi contoh kehidupan pasien di sel rumahsakit atau narapidana di sel penjara yang tidak mampu melawan karenakontrol dari otoritas pemegang kekuasan, seperti dokter rumah sakit dansipir penjara yang demikian ketat.

Sampai disini, apa sebenarnya pokok gagasan yang hendakdisampaikan Foucault? Disinilah kita akan sampai pada kekuatan wacanamelalui bahasa sebagai mesin pembentuk makna. Menurut Foucault, wacana memiliki kemampuan menciptakan pengetahuan manusia. Foucault memfokuskan seluruh karyanya pada mekanisme sentral ilmu-ilmusosial pada penggolongan orang yang normal dan abnormal. Kitasesungguhnya mendefenisikan yang normal melalui yang abnormal. Hanya melalui abnormalitas kita mengetahui yang normal. Maka dari itu, meskipun abnormalitas disingkirkan atau disembunyikan, orang-orangyang normal selalu mempelajari dan mempertanyakannya. Saat Foucaultsedang berbicara tentang sejarah kegilaan, sesungguhnya kita tidak akanpernah sampai pada 'makna kegilaan' yang sebenarnya, yaitu yang absolut dan mutlak. Sejarah kegilaan yang kita peroleh merupakanwacana atau pendapat orang-orang yang berbicara tentang kegilaan, tetapibukan kegilaan itu sendiri. Kita mengetahui kegilaan (abnormal) karenakita menghadapkannya pada suatu yang

17Iswandi Syahputra, "Post Media Literacy: Menyakksikan Kuasa Media Bersama Michel Foucault”, Jurnal Aspikom, volume 1 nomor 1 (juli, 2010), 6. 
normal. Padahal, sesuatu yangnormal itu hanya merupakan mayoritas kesepakatan bersama melaluiproses normalisasi.

Sebenarnya yang hendak disampaikan Foucault adalah menunjukkan bahwa kita adalah bagian dari mekanisme kekuasaan itu. Dari kesadaran akan lahir kesanggupan untuk menggunakan kekuasaan secara baik, demi kepentingan orang lain bukan semata untuk kepentingan pribadi. Keterarahan pada orang lain hanya lahir dari kesadaran diri sendiri dalam konstelasi kekuasaan. Yang menjadi masalah dalam kehidupan adalah bahwa banyak orang tidak menyadari perannya dalam peta kekuasaan. Jika saja paling tidak banyak orang sadar akan hal ini dan aktif menyuarakannya, maka orangpun akan menerima dan menghargai pluralitas peran yang ada dalam relasi kekuasaan. Dari ketidaksadaran ini akan lahir berbagai tindakan dan sistem yang menindas dan menyeragamkan.18

\section{Sejarah dan Profil Pengurus Cabang Pergerakan Mahasiswa Islam Indonesia Kabupaten Malang.}

Cabang Pergerakan Mahasiswa Islam Indonesia (PMII) kabupaten Malang berdiri pada tanggal 24 April 1999,organisasi ini adalah organisasi yang bergerak dibidang kemahasiswaan khususnya kader-kader Nahdlatul Ulama ditingkatan Mahasiswa. Organisasi ini memiliki jenjang kepengurusan mulai dari tingkatan Rayon atau setara fakultas, Komisariat Setara Universitas, Pengurus Cabang Setara Kabupaten dan Kota, Pengurus Koordinator Cabang setara tingkatan provinsi, Pengurus Besar setara Nasional.

Pengurus Cabang PMII Kabupaten malang ini memiliki wilayah di kabupaten malang, yang mana memiliki beberapa kepengurusan rayon dan komisariat yang ada dibawah naungannya. Diantaranya Rayon RPGM, RCSP, RBJT, RPP, RPA, RPU, RPMA, RLA dan Komisariat RR, Al-qolam, Ibnu Sina, KH Moch Said yang bersifat definitif atau sah dan mendapat Surat Keterangan dari cabang. Setiap komisariat dan rayon definitif harus aktif melaksanakan kaderisasi formal, informal dan non formal.

Secara wilayah, Malang Raya ini terpecah menjadi 3 bagian. Yakni kabupaten Malang, Kota Batu, dan Kota Malang. Jika

18Abdullah Khozin Af, "Konsep Kekuasaan Michel Foucault", Teosofi: Jurnal Tasawnf dan Pemikiran Islam, volume 2 nomor 1 (juni, 2012), 147. 
berbicara PMII yang ada ditingkatan cabang. PMII ini hanya ada di 2 wilayah di malang raya ini, Yakni di Kota Malang dan Kabupaten Malang. Sedangkan kota batu belum memiliki Cabang PMII, Namun tidak menutup kemungkinan PMII akan juga berdiri disana, mengingat kampus juga sudah ada.

Namun secara keluasan wilayah, kabupaten malang ini adalah wilayah terluas di wilayah Malang Raya. Menurut data di wikipediaSebagian besar wilayah Kabupaten Malang merupakan kawasan daratan tinggi dan pegunungan yang berhawa sejuk. Bagian barat dan barat laut berupa pegunungan, dengan puncaknya Gunung Arjuno (3.339 m) dan Gunung Kawi (2.651 m).

Tugas dari Pengurus Cabang PMII Kabupaten Malang menjalankan Roda kaderisasi sesuai tujuan PMII di AD/ART PMII Bab 4 ayat 4. Yakni "Terbentuknya Pribadi muslim Indonesia yang bertaqwa kepada Allah SWT, berbudi luhur, berilmu, cakap dan bertanggung jawab dalam mengamalkan ilmunya serta komitmen memperjuangkan cita-cita kemerdekaan Indonesia". Dalam menjalankan tujuan tersebut PMII Kabupaten Malang secara wilayah cabang juga turut mengawal pemerintahan, isu masyarakat dan beberapa hal yang memang berkenaan dengan Wilayah kabupaten Malang secara khusus dan tentunya mengawal isu-isu nasional yang sedang berkembang dan sekiranya dapat mempengaruhi masyarakat kabupaten malang.

1. Program PC PMII Kab. Malang periode 2018-2019

Ada sejumlah program dari PC PMII Kab. Malang periode 2018-2019 yang mengarah kepada peningkatan sumberdaya manusia dan Soft Skill dari setiap kader dan anggota PMII yang ada di seluruh Komisariat dan Rayon. Mulai dari peningkatan intelektual kader baik laki-laki maupun perempuan. Yang realita hari ini banyak kader yang sering menyalahkan posisi peran perempuan dan laki-laki dan itu secara disadari atau tidak menjadi hal yang sangat biasa dan dianggap sebagai hal yang tidak bermasalah atau bisa dikatakan membudaya. Contoh yang sering kita temui dalam ranah intelektual atau pembacaan forum antara laki-laki dan perempuan adalah, perempuan cenderung diam ketika diminta untuk berpendapat, berbeda dengan laki-laki yang memang sering menjadi singa dalam sebuah forum. 
Ada juga beberapa kaderisasi informal yang sering kita coba sampaikan kepada kader-kader secara peran, Misalnya pemahaman bahwa menjadi seorang ketua, tidak harus seorang laki-laki, tapi perempuan juga mampu untuk menjadi seorang pemimpin. Karena untuk mampu dalam melakukan tugas seorang ketua dalam ranah publik tidak ditentukan oleh jenis kelamin, melainkan kemampuan.

Adapun agenda yang memang disiapkan untuk menjadi penunjang kader PMII untuk mampu memahami apa yang sudah menjadi keresahan bersama selama ini didalam tubuh PMII khususnya PMII Kabupaten Malang.

a. Kajian tentang perempuan

Dalam dunia PMII ada yang namanya macam-macam proses kaderisasi. Yang pertama kaderisasi formal, non formal dan informal. Kajian perempuan ini disampaikan dalam 3 metode ini, mulai dari formal, yang mana di materi MAPABA disampaikan tentang Gender, Di PKD Disampaikan tentang Nahdatun Nisa' dan di PKL disampaikan materi Gerakan Perempuan dalam ranah Nasional, Kemudian kaderisasi Non Formal misalnya berbentuk pelatihan. Konsep dari pelatihan ini nantinya menyampaikan materi tentang perempuan, Feminisme dan hal lain yang berkaitan dengan perempuan. Yang terakhir adalah Informal yang mana dalam sebuah kepanitian memberikan ruang kepada kader perempuan ditempat-tempat yang maskulin dan dari situ kita memiliki salah satu tolak ukur penilaian mampu atau tidaknya kader menjalanlan tanggung jawab itu.

b. Mendirikan Forum Perempuan Cipayung Malang Raya

Dengan adanya forum ini, akan menjadi salah satu wadah untuk meperluas forum perempuan dan tempat untuk bertukar pandangan dengan sesama perempuan memiliki ranah yang lebih luas dan bisa dijadikan sebagai forum penyebaran virus untuk menyampaikan posisi perempuan.

c. Terjun ke masyarakat untuk ANSOS isu perempuan

Dalam agenda ini berkaitan dengan ranah sosial yang dijadikan sebagai tenpat penempaan teori yang sudah 
dipelajari dan mengkorelasikannya di dunia nyata, sebelum benar-benar bersatu dengan masyarakat.

\section{Analisis Data dan Pembahasan}

Dalam bab ini akan menyampaikan bahasan dan juga analisis data mengenai eksploitasi tubuh perempuan dalam pelaksanaan program kerja pengurus cabang Pergerakan Mahasiswa Islam Indonesia (PMII) kabupaten Malang.Seperti yang telah dikemukakan di bab 3, data yang terkumpul dalam penelitian ini diperoleh dengan menggunakan teknik pengumpulan data observasi dan wawancara.Dalam bab ini juga sekaligus akan menjawab 2 pertanyaan rumusan masalah yang tertera di bab 1.2 rumusan masalah tersebut adalah sebagai berikut: bagaimana praktik eksploitasi tubuh aktivis perempuan di PC PMII kabupaten Malang? Dan bagaimana disiplin tubuh Michel Foucault memandang eksploitasi tubuh aktivis perempuan di PC PMII kabupaten Malang?Data yang diperoleh dari hasil pengamatan dan juga wawancara dari beberapa responden akan dianalisis menggunakan teori disiplin tubuh atau disciplinery power Michel Foucault.

Dalam bab 1 dan bab 2 peneliti telah mengungkapkan bahwa teori yang akan digunakan untuk mengupas eksploitasi tubuh pada aktivis perempuan ini adalah teori dari Michel Foucault. Disiplin tubuh yang dimaksud adalah orang mematuhi segala peraturan yang telah ada dalam suatu institusi atau organisasi tanpa terpaksa dan melakukannya begitu saja, tanpa takut siksaan yang akan mendatangi tubuhnya ketika dia tidak melaksanakan peraturan yang sudah disepakati bersama. Ada sistem bernama panopticon. Sistem ini menjadi pengawas terhadap semua yang berada pada satu wilayah tersebut untuk mematuhi peraturan yang sudah ada dan memastikan tubuh individu menjadi patuh dan taat terhadap peraturan atau disiplin yang sudah menjadi kebijakan seseorang yang memiliki kuasa. Dalam penelitian ini sistem panopticon tersebut digunakan dan ditempati oleh pengurus cabang, pengurus komisariat, pengurus rayon ataupun kepanitian dalam setiap kegiatan untuk memastikan bahwa semua mematuhi peraturan yang sudah terbetuk dan disepakati bersama.

\section{Praktik Eksploitasi Tubuh Aktivis Perempuan}


Melihat data hasil wawancara dan observasi yang peneliti telah cantumkan di bab 3, praktik eksploitasi yang terjadi dilapangan tidak seperti penjabaran arti eksploitasi yang tercantum di bab 1, seperti memaksakan para aktivis perempuan memakai pakaian yang mini dan ketat, kemudian dipertontonkan di khalayak umum untuk mendapatkan kapital yang besar dan digunakan untuk berjalannya roda organisasi tersebut. Tetapi, eksploitasi yang ada di pelaksanaan program kerja ini, memandang segala sesuatu yang mengambil manfaat dari seseorang baik disengaja maupun tidak itu adalah bentuk dari eksploitasi.

Eksploitasi tubuh aktivis perempuan yang terjadi pada pelaksanaan program kerja ini ada pada bagian:

1. aktivis perempuan dipaksa untuk mengikuti suatu kegiatan dengan tujuan agar dapat meningkatkan kepercayaan diri dan mendapat pengalaman, dan setelahnya akan diberi tanggung jawab untuk mengadakan acara yang serupa atau menangani hal serupa.

2. aktivis perempuan dipaksa untuk mengemban 1 posisi dalam kepengurusan atau kepanitiaan tanpa pengalaman terlebih dahulu dengan alasan pasti akan bisa dengan seiring berjalannya waktu dan disepakati oleh banyak orang,

3. aktivis perempuan ada yang terpaksa melaksanakan tugas temannya dikarenakan temannya tidak mengerjakan apa yang seharusnya dikerjakan sesuai dengan job deskripsinya,

4. ada penolakan dari sebagian aktivis laki-laki maupun perempuan terhadap kegiatan pengembangan keperempuanan,

5. Ada juga aktivis perempuan yang masih berjuang untuk mendapatkan restu dari orang tuanya. Karena orang tuanya tidak suka jika dia sering berkegiatan di luar apa lagi berkumpul dengan lawan jenisnya.

Peneliti akan membahas poin-perpoin untuk menjelaskan kenapa ini bisa dikatakan eksploitasi pada tubuh aktivis perempuan. Poin satu, pemaksaan untuk mengikuti kegiatan yang tidak dia ketahui maksud dan tujuannya adalah salah pengambilan manfaat yang bisa dikatakan itu adalah eksploitasi. Apalagi jika setelah kegiatan itu berakhir aktivis tersebut diberi tanggung jawab untuk menangani hal serupa. 
Poin kedua, mengemban suatu jabatan tanpa pengalaman sebelumnya adalah pemanfaatan tubuh dari aktivis perempuan tersebut, aktivis tersebut dipandang cukup bisa dimanfaatkan untuk menjadi pengisi kekosongan yang terjadi dalam satu kepengurusan atau kepanitiaan.

Poin ketiga, aktivis perempuan harus menangani tugas yang seharusnya dikerjakan oleh temannya. Karena temannya tidak bertanggung jawab atau tidak bisa melaksanakan tugas tersebut. Kenapa bisa seperti ini? Dikarenakan pembagian tugas tidak sesuai dengan kemauan dan kemampuan yang akhirnya menyebabkan dia menjadi sasaran dari ketua untuk melaksanakan tugas-tugas yang temannya tidak bisa melaksanakan tugasnya.

Poin keempat, ada penolakan dari aktivis lain baik perempuan maupun laki-laki. Bagi perempuan, mereka yang misoginis dan sudah terlanjur nyaman dalam posisi subordinasi akan memberontak jika diajak untuk mengadakan agenda pengembagan keperempuanan. Bagi laki-laki, mereka yang misoginis jelas akan menolak keberadaan gerakan-gerakan keperempuanan dengan alasan akan menghambat kegiatan yang lain.

Poin kelima, budaya patriarki di dalam masyarakat memang masih cukup kental apalagi mereka yang tinggal didaerah perkampungan dan didaerah pondok pesantren. Hanya untuk dapat berkegiatan dan mengembangkan bakat dia harus berjuang meyakinkan orang tuanya bahwa kegiatan yang akan dilakukannya bermanfaat untuk masa depannya. Dikarenakan budaya patriarki yang cukup kental maka alasan tersebut ditolak dengan alasan bahwa perempuan itu pandai masak, anggun, diam dan lain-lain. Dalam bentuk ini, eksploitasi nya dilakukan oleh budaya patriarki yang sudah mengakar dalam masayarakat.

Akan tetapi, eksploitasi ini berjalan dan dilakukan rata-rata ketika mereka baru saja memasuki dunia organisasi. Ketika para aktivis ini baru mengenal dunia organisasi dan belum paham sepenuhnya tentang cara kerja sebuah organisasi. Eksploitasi akan berhenti dilaksanakan ketika para aktivis dapat bersuara mengeluarkan pendapat mereka sendiri dengan tegas. Ketegasan mereka dapatkan ketika mereka mulai mengikuti diskusi dan kajian formal maupun informal. Kaderisasi formal seperti Pelatihan Kader 
Dasar (PKD), Sekolah Islam Gender (SIG), Sekolah Kader Kopri (SKK) dan beberapa rencana tindak lanjut dari setiap acara yang mereka ikuti. Setelah mereka mendapat ilmu didalam kaderisasi tersebut, eksploitasi dalam pelaksanaan program kerja akan sangat menurun. Bisa peneliti simpulkan bahwa eksplotasi akan tetap terjadi jika pengetahuan aktivis tersebut tidak memadai atau kurang memadai.

\section{Disiplin Tubuh Michel Foucault Memandang Eksploitasi Tubuh Aktivis Perempuan}

Dalam buku terjemahan karya Petrus Sunu Hardiyanto19 menerangkan tentang Diciplin and Punishment. Dalam buku ini ditulis bahwa Foucault hendak mengetengahkan relasi kekuasaan yang bergerak melalui wacana berakibat pada rasa sakit pada tubuh manusia. Pengamatannya pada praktek disiplin penjara membuktikan hal itu. Foucault memulai pergerakan wacana dengan menyampaikan kisah sejarah tentang hukuman yang terus bergeser sesuai zamannya. Sistem hukuman yang berpusat pada rasa sakit yang dipertontonkan secara terbuka menjadi tidak terkontrol dan dapat memicu kerusuhan atau huru hara politik. Seluruh sistem hukuman yang berpusat pada rasa sakit dirancang dan dijalankan lantas direduksi menjadi satu hukuman untuk semua jenis kejahatan, hukuman penjara. Masyarakat sudah terbiasa dengan wacana ini dan sulit untuk kembali pada wacana hukuman mati yang dipertontonkan secara terbuka sebelumnya. Dalam penjara terdapat satu bangunan yang dirancang untuk mengawasi seluruh tahanan. Desain bangunan ini dinamakan Panopticon. Panopticon berfungsi sebagai tempat pengawasan tahanan yang ditempati oleh sipir penjaga tahanan untuk memastikan para tahanan yang ada didalamnya melaksanakan disiplin yang sudah menjadi peraturan tahanan.

Teknologi politis ini,20 memastikan tubuh individu menjadi patuh dan taat terhadap peraturan atau disiplin yang sudah menjadi kebijakan seseorang yang memiliki kuasa. Teknologi politis ini

19Petrus Sunu Hardiyanto, Disiplin Tubub Bengkel Individu Modern (yogyakarta: LKiS, 1997), 22.

20Ibid, 34. 
sampai detik ini diterapkan kedalam penjara-penjara dan rumah sakit-rumah sakit, yang tentunya digunakan untuk mempermudah pelayanan. Sebagai contoh teknologi politis ini adalah semua individu yang masuk kedalam institusi tersebut akan dicatat seluruh data dirinya dengan tujuan untuk memudahkan mengenali dan menganalisisnya untuk diperbaiki kedisiplinannya.

Memang jika berbicara tentang disiplin tubuh maka tidak akan luput dari pembahasan tentang kekuasaan dan pengetahuan. Karena kekuasaan akan melahirkan peraturan-peraturan yang akan diterapkan oleh mereka yang berkuasa dan akan dijalankan oleh mereka yang tidak memiliki kekuasaan. Kekuasaan itu tersebar, berada dimana-mana, tidak terpusat, terdapat disetaip relasi sosial. Bukan karena kekuasaan dapat mengkonsolidasikan segala sesuatu dibawah kondisi ketidaknampakkannya, tetapi kekuasaan selalu diproduksi dalam setiap momen dan setiap relasi. Kekuasaan itu tidak merengkuh semua menjadi satu melainkan semua berkumpul menjadi satu. Disiplin tubuh adalah salah satu konsep penerapan dari kekuasaan tersebut.21 Disiplin tubuh bekerja sebagai normalisasi kelakuan yang didesain dengan memanfaatkan kemampuan produktif dan reproduktif dari tubuh manusia.22Dalam penelitian ini tubuh yang didisiplinkan secara tidak langsung tereksploitasi oleh pendisiplinan yang dilakukan oleh yang memiliki kekuasaan. Meskipun disiplin tubuh itu memanfaatkan kemampuan produktif dan reproduktif tubuh, tetapi kenyataannya memang pendisiplinan yang dilakukan oleh penguasa terkadang bersifat eksploitatif. Pendapat peneliti ini didukung oleh jurnal Umar Kamahi, didalam jurnalnya dia menulis, "kekuasaan model ini pada intinya berusaha menciptakan situasi dimana tubuh individu dapat menginternalisasikan penundukan dan menjadikannya seolah

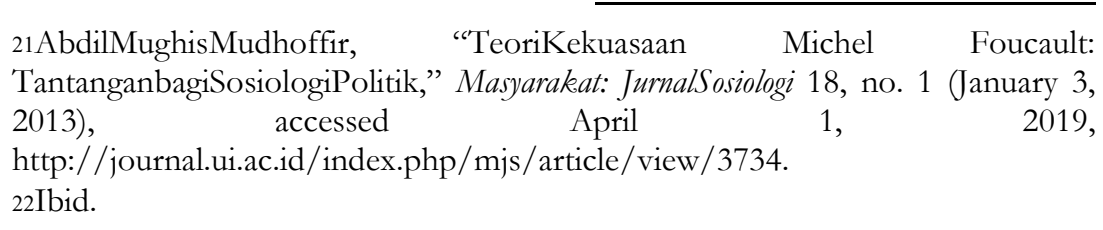


sebagai suatu keadaan yang normal." 23 Praktik seperti inilah yang disebutkan Foucault sebagai normalisasi dari berlangsungnya kekuasaan terhadap tubuh individu. Individu tida akan pernah merasa meraka sedang dimanfaatkan dan ditundukkan karena mereka sudah menganggap hal itu sesuai batas kewajaran. Bisa dikatakan juga bahwa ini adalah eksploitasi yang terselubung.

\section{Penutup}

Praktik eksploitasi tubuh aktivis perempuan dalam pelaksanaan program kerja Pengurus Cabang Pergerakan Mahasiswa Islam Indonesia Kabupaten Malang ini memanfaat aktivis perempuan untuk keberlangsungan kepengurusan maupun keberlangsungan sebuah kepanitiaan. Demi terlaksanya acara yang bagus dan menarik para pemilik kekuasaan memanfaat aktivis perempuan untuk menjadi pelangkap, seperti dia melaksanakan tugas yang tidak sesuai dengan deskripsi kerjanya, mendapat paksaan dari teman sesama aktivis untuk melaksanakan tugas yang dia sendiri belum berpengalaman dan baru pertama mencobanya, dan yang paling mencolok adalah ketika sesama aktivis perempuan tidak senang jika ada program pengembangan keperempuanan. Ternyata misoginis juga bisa berasal dari aktivis kaum perempuan itu sendiri. Mereka sudah terlalu nyaman dalam keadaan yang subordinasi dan tidak mau beranjak untuk keluar dari zona nyaman tersebut. Tetapi, eksploitasi akan tetap berlangsung jika pengetahuan dari individu tersebut tidak bertambah atau dia hanya keilmuannya tidak bertambah sedikitpun.

Pendangan teori disiplin tubuh Michel Foucault tentang eksploitasi tubuh aktivis perempuan dalam pelaksanaan program kerja Pengurus Cabang Pergerakan Mahasiswa Islam Indonesia Kabupaten Malang Disiplin tubuh bekerja sebagai normalisasi kelakuan yang didesain dengan memanfaatkan kemampuan produktif dan reproduktif dari tubuh manusia.Dalam penelitian ini tubuh yang didisiplinkan secara tidak langsung tereksploitasi oleh pendisiplinan yang dilakukan oleh yang memiliki kekuasaan.

23Umar Kamahi, “Teori Kekuasaan Michael Foucault: Tantangan Bagi Sosiologi Politik," Jurnal Al-Khitabah 3, no. 3 (June 1, 2017), accessed July 17, 2019, http://journal.uin-alauddin.ac.id/index.php/Al-Khitabah/article/view/2926. 
Meskipun disiplin tubuh itu memanfaatkan kemampuan produktif dan reproduktif tubuh, tetapi kenyataannya memang pendisiplinan yang dilakukan oleh penguasa terkadang bersifat eksploitatif. Pendapat peneliti ini didukung oleh jurnal Umar Kamahi, didalam jurnalnya dia menulis, "kekuasaan model ini pada intinya berusaha menciptakan situasi dimana tubuh individu dapat menginternalisasikan penundukan dan menjadikannya seolah sebagai suatu keadaan yang normal."24 Praktik seperti inilah yang disebutkan Foucault sebagai normalisasi dari berlangsungnya kekuasaan terhadap tubuh individu. Individu tida akan pernah merasa meraka sedang dimanfaatkan dan ditundukkan karena mereka sudah menganggap hal itu sesuai batas kewajaran. Bisa dikatakan juga bahwa ini adalah eksploitasi yang terselubung

\section{Daftar Pustaka}

Abdil Mughis Mudhoffir. "Teori Kekuasaan Michel Foucault: Tantangan bagi Sosiologi Politik," dalam Jurnal Masyarakat: Jurnal Sosiologi, Vol. 18, No. 1 Januari, 2013.

Abdullah Khozin Af. 'Konsep Kekuasaan Michel Foucault', dalam Jurnal Teosofi: Jurnal Tasawnf dan Pemikiran Islam, Vol. 2 No. 1, Juni, 2012.

Amirul Hadi dan H. Haryono. Metodologi Penelitian Pendidikan. Bandung: Pustaka Setia, 1998.

Ayu Handani..Ekploitasi tubuh perempuan pada sales promotion girl (studi kasus komunikasi non verbal sales promotion girl produk rokok). Salatiga: Universitas Kristen Satya Wacana, 2015.

John W Creswell.. Penelitian Kualitatif \& Desain Riset. Yogyakarta: Pustaka Pelajar,2015.

Dio Pratama. Eksploitasi Tubuh Perempuan Dalam Film "Air Terjun Pengantin” Karya Rizal Mantovani. eJournal Ilmu Komunikasi. Universitas Mulawarman. Volume 4, 2014.

Hadari Nawawi. Metodologi penelitian Bidang Sosial. Yogyakarta: Gajah Mada University press, 2001.

24Umar Kamahi, “Teori Kekuasaan Michael Foucault: Tantangan Bagi Sosiologi Politik," Jurnal Al-Khitabah 3, no. 3 (June 1, 2017), accessed July 17, 2019, http://journal.uin-alauddin.ac.id/index.php/Al-Khitabah/article/view/2926. 
Ignatius Prasetyo Wicaksono, "Representasi Eksplotasi Perempuan dalam Iklan", dalam Jurnal Ilmu Komunikasi, Vol. 9 No. 2, Desember 2012.

Iswandi Syahputra, 'Post Media Literacy: Menyakksikan Kuasa Media Bersama Michel Foucault', dalam Jurnal Aspikom, Vol. 1 No. 1, Juli, 2010.

K. Bertens, Filsafat Barat Kontemporer Prancis, Jakarta: Gramedia, 2001.

M.Syamsudin."Eksploitasi Wanita dalam Perspektif Kapitalis", Ejurnal Egalita, Vol. 1, No. 2, 2006.

Merly Natalia Lago, 'Eksploitasi tubuh Perempuan di Media Televisi (Analisis Semiotika Makna Pesan Iklan Cat Avian Syntetic Versi Awas Cat Basah), dalam Jurnal Kinestetik, Vol 4 No. 2, 2017.

Michel Foucault, Seks dan Kekuasaan, terj. S. H. Rahayu, Jakarta: Gramedia, 2000.

Nur Afta Lestari, "Eksploitasi Pada Permpuan Sales Promotion Girls", dalam Jurnal Komunitas, Vol. 4 No. 2, Juni, 2012.

Petrus Sunu Hardiyanto, Disiplin Tubuh Bengkel Individu Modern, Yogyakarta: LKiS, 1997.

Siswantoro, Metode Penelitian Sastra: Analisis Psikologis.Surakarta: Sebelas Maret University Press, 2004.

Siti Hariti Sastriyani Sugiharti. Glosarium Seks Dan Gender. Yogyakarta : Carasvati Books, 2007.

Syamsudin. Eksploitasi Wanita dalam Perspektif Kapitalis. E-jurnal Egalita. 1 (2): 20-40, 2006.

Umar Kamahi, 'Teori Kekuasaan Michael Foucault: Tantangan Bagi Sosiologi Politik, dalam Jurnal Al-Khitabah, Vol. 3 No. 3, Juni 2017.

"Hasil Muspimnas - Pergerakan Mahasiswa Islam Indonesia," accessed May 8, 2019, https://pmii.or.id/hasil-muspimnas/.8. Artikel dalam Internet - Wawan Junaidi, "Pengertian Masyarakat," dalam http://wawanjunaidi.blogspot.com/2012/03/pengertianmasyarakat.html 05/diakses23-juli 2015 